\title{
Survey on Total Quality Management in Small and Medium Manufacturing Industries in Shah Alam
}

\author{
Mohd Rashdan Isa ${ }^{1}$, Omar Suliman Zaroog ${ }^{1}$, Sivabalan A/L Raju ${ }^{1}$ \\ ${ }^{1}$ Department of Mechanical Engineering, Universiti Tenaga Nasional, Kajang, 43000, Malaysia
}

\begin{abstract}
Recognition of quality management as a significant factor holds the key to competitiveness in the global market regardless of the size of the company. Total Quality Management (TQM) practices are primarily found in larger and multinational organizations but little has been written on how TQM has been applied in SMEs of Malaysia. This project reports the results of a full survey conducted among a sample of local SMEs in Shah Alam, Malaysia. The survey conducted in this project revealed the level of TQM implementation in the manufacturing industry via a direct visit to the company and by online questionnaire. The survey covered 100 company chosen from many manufacturing industries and produced a response rate of 57.0 percentages. Internal quality audit is used mostly as quality activity. Moreover, leadership and support from top management is perceived to be the top critical success factor (CSFs) in TQM implementation. Lack of experience in quality management is perceived as top barriers for TQM implementation with $77.2 \%$ agreed to it. The result finding is expected to be significant information for future research directions especially as an indicator for the significant information for future research directions especially as an indicator for the development of a suitable TQM framework for the SMEs in Shah Alam and also other local SMEs in Malaysia.
\end{abstract}

Keywords: Total Quality Management, Small and Medium Manufacturing Industries.

\section{Introduction}

As shown by the various publications done over years, quality management has been accepted as an important aspect in aiding a company to move forward in this era of globalization. To hold their market share, remain competitive, and to respond to fluctuating competitive demand in business world, many companies apprehend that TQM is a necessity even though not all companies had a successful implementation of TQM. Compared to large industries, SMEs have been slow in the manner of adopting TQM and has focused mainly on ISO 9000 certification, and only few had gone beyond that (Yusof, 2000). An organization that adopts TQM approach will survive and also will be competent in business world. The rate of imported goods and services into the country had been continuously increasing in believe that they are of high quality.

A critical need for TQM analysis and development of specific implementation model that follow the context was created due to the industrial growth in Malaysia. For TQM allied to widespread knowledge and interest, there are many high level of social and governmental aid. Malaysian organization makes TQM research more interesting and informative because of their intensities and complexities (Mohamad Reeduan, 2011).

Therefore, it had been decided to do the research of identifying the current level of TQM implementation as well as to identify the CSFs and the barriers for quality adoption in this area. Following an intense study on literature review, this paper has a description of the methodology utilized in this study and followed by results and analysis from the survey. A general description of the survey respondents is being presented, followed by the level of quality practices in the companies, continued by an analysis on CSFs and barriers for TQM implementation. The paper concludes with a summary highlighting the important findings from this study and future research directions.

\section{Literature Review}

Different definition has been agreed on Total Quality Management (TQM) by quality practitioners, gurus and academician based on their point of view throughout the history of quality development. TQM is defined in threeword definition (Ho 1999); Total for every person is involved, quality for customer demand is met precisely and management for senior executives is fully committed. Besterfield (1995) defined TQM as a philosophy and also as a set of directorial principles that characterizes the foundation of a continuously improving organization that assimilates fundamental management techniques, technical tools under a disciplined approach and existing improvement efforts (Quek Eng Eng 2003). TQM is a state of mind that gets to be focus bit of an association and is characterized as administration as well, rationality and an arrangement of standards which controls each individual from association who included in the ceaseless change procedure to meet consumer loyalty (Dhillon 2005).

TQM essentially require a social change that needs worker association at all levels and a soul of solidarity among clients, suppliers, representatives and directors as representative contribution, investment and strengthening shape the establishments of TQM (Saylor 1992).

A study found that there is an arrangement of eight critical factors of quality management which is derived mainly from the extensive reading and research by (Saraph, 1989). According to the experts, critical success factors is a management term for an element that is necessary for an organization or project to achieve its mission and its necessary to ensure the success of a company or an organization. Critical factors was developed for TQM as a framework is needed in order to measure the extent of 


\section{International Journal of Science and Research (IJSR) \\ ISSN (Online): 2319-7064 \\ Index Copernicus Value (2013): 6.14 | Impact Factor (2014): 5.611}

practice as no one at that particular timeline took the initiative to theorize and formalize TQM (Saraph, 1989). The second approach was to find vital and necessary methods for making TQM adoption success (Ahire, 1996). The researcher trusts that these set of critical factors figured to address the administrative problem faced by the companies.

\section{Methodology}

The objective of this study was to investigate the level of implementation of TQM, CSFs and barriers for TQM implementation in Shah Alam manufacturing SMEs. Keeping that in mind, a questionnaire was created, developed and modified to reach the objective of this study. A sum of 8 constructs will be composed with little alterations made from 10 constructs (S.Yusof 1999). Having validated the questionnaire through expert validation and pilot testing, sample of 100 manufacturing companies were randomly selected from Shah Alam through the list of companies by convenience sampling. The full survey, through meeting personally the responsible personnel of the company and through online questionnaire, was carried out. The response rate was $57 \%$. The analysis of data was done using Statistical Package Analysis Version 20.0.

\section{Result}

The general profile of the respondents were analysed as shown in Table 1. In this, it is shown the breakdown of the SMEs based on its nature. The largest proportion of the respondents belongs to Petroleum, Chemical and Plastic sector $(24.56 \%)$.

Table 2 shows that $56.14 \%$ of the respondents have 5 fulltime quality personnel in their Quality Management sector. This shows that the respondent companies have awareness on the importance of quality and has taken initiative to supervise their product or service quality over time.

Table 1: Business nature by respondents

\begin{tabular}{|c|c|c|c|c|c|}
\hline \multicolumn{2}{|c|}{} & Frequency & Percent & $\begin{array}{c}\text { Valid } \\
\text { Percent }\end{array}$ & $\begin{array}{c}\text { Cumulative } \\
\text { Percent }\end{array}$ \\
\hline \multirow{7}{*}{} & Automotive & 4 & 7.0 & 7.0 & 7.0 \\
\cline { 2 - 6 } & $\begin{array}{c}\text { Petroleum, } \\
\text { Chemicals, and } \\
\text { plastics }\end{array}$ & 14 & 24.6 & 24.6 & 31.6 \\
\cline { 2 - 6 } Valid & Food Production & 8 & 14.0 & 14.0 & 45.6 \\
\cline { 2 - 6 } & $\begin{array}{c}\text { Metal } \\
\text { Manufacturing }\end{array}$ & 6 & 10.5 & 10.5 & 56.1 \\
\cline { 2 - 6 } & $\begin{array}{c}\text { Wood, Paper, and } \\
\text { Leather }\end{array}$ & 8 & 14.0 & 14.0 & 70.2 \\
\cline { 2 - 6 } & $\begin{array}{c}\text { Electricals and } \\
\text { electronics }\end{array}$ & 8 & 14.0 & 14.0 & 84.2 \\
\cline { 2 - 6 } General Machinery & 9 & 15.8 & 15.8 & 100.0 \\
\cline { 2 - 6 } & Total & 57 & 100.0 & 100.0 & \\
\hline
\end{tabular}
www.ijsr.net 


\section{International Journal of Science and Research (IJSR) \\ ISSN (Online): 2319-7064 \\ Index Copernicus Value (2013): 6.14 | Impact Factor (2014): 5.611}

The two least implemented quality activities are Six-sigma program and Design of Experiment. These quality activities with less than $20 \%$ degree of usefulness are those, which are entirely exceptional and hard to actualize or practice. They require exceptional knowledge and set of skills, which likely the most part of these SMEs do not have, because of high application costing, and needy expertise in specifically in area of quality implementation.

Table 4: Degree of Usefulness of Quality Activity

\begin{tabular}{|c|c|c|}
\hline Remarks & Quality Activities & Percent of Usefulness \\
\hline \multirow{4}{*}{$\begin{array}{c}\text { Very High Degree of Usefulness (80\% - } \\
100 \%)\end{array}$} & Internal Quality Audit & 98.2 \\
\cline { 2 - 3 } & Quality Costing & 83 \\
\cline { 2 - 3 } & Benchmarking & 82.5 \\
\cline { 2 - 3 } & QS - Housekeeping & 80.7 \\
\cline { 2 - 3 } High Degree of Usefulness (50\% - 79\%) & Quality Awareness Program & 60.7 \\
\cline { 2 - 3 } & Acceptance Sampling & 68.4 \\
\hline \multirow{3}{*}{ Medium Degree of Usefulness (21 -49\%) } & Quality Circle/Quality Improvement Team & 54.4 \\
\cline { 2 - 3 } & Total Productive Maintenance (TPM) & 43.9 \\
\cline { 2 - 3 } & Statistical Process Control & 36.8 \\
\cline { 2 - 3 } & Quality Function Deployment (QFD) & 29.8 \\
\hline \multirow{2}{*}{ Low Degree of Usefulness (0\% - 20\%) } & Supplier Improvement Activities & 24.6 \\
\cline { 2 - 3 } & Problem Solving Technique & 22.8 \\
\hline
\end{tabular}

\subsection{Critical success factor}

Table 6 shows that the respondents had chosen leadership and support from top management $(93.0 \%)$ as the top critical factor that will affect the performance of the company. This is followed by selective application of tools and technique
(56.1\%) and adopting quality assurance system (56.1\%) which had a tie. With (49.1\%), conducting continuous improvement and with (47.4\%), sufficient financial resources completes the top 5 critical factor that affect the performance of the company.

Table 5: Top 5 Critical Factor That Affect the Performance of Company

\begin{tabular}{|c|c|c|c|c|}
\hline & \multicolumn{2}{|c|}{ Responses } & \multirow{2}{*}{$\begin{array}{l}\text { Percent of } \\
\text { Cases }\end{array}$} \\
\hline & & $\mathrm{N}$ & Percent & \\
\hline \multirow{12}{*}{$\begin{array}{l}\text { Top } 5 \text { Critical Factor That } \\
\text { Affects the Performance of } \\
\text { Company }\end{array}$} & Leadership and support from top management & 53 & 18.7 & 93.0 \\
\hline & Conducting continuous improvement & 28 & 9.9 & 49.1 \\
\hline & Measuring results and performance & 26 & 9.2 & 45.6 \\
\hline & Selective application of tools and technique & 32 & 11.3 & 56.1 \\
\hline & Involving supplier in activities & 19 & 6.7 & 33.3 \\
\hline & Desirable human resource practice & 20 & 7.0 & 35.1 \\
\hline & Adopting quality assurance system & 32 & 11.3 & 56.1 \\
\hline & Sufficient financial resources & 27 & 9.5 & 47.4 \\
\hline & Providing relevant training for senior management & 11 & 3.9 & 19.3 \\
\hline & Providing effective and appropriate training for employees & 20 & 7.0 & 35.1 \\
\hline & Favourable work environment and culture & 16 & 5.6 & 28.1 \\
\hline & Total & 284 & 100.0 & 498.2 \\
\hline
\end{tabular}

\subsection{Barriers for TQM implementation}

Referring to Table 7, the respondents had chosen five top barriers for TQM Implementation in SMEs. With the weightage of $77.2 \%$, respondents believe that lack of experience in quality management is the top barriers in implementing TQM in SMEs. Many SMEs reluctant to invest in quality management, as they fail to see the bigger picture and the positive effect it can have on the management and production. Many SMEs who are starting to implement TQM have inexperienced managers in quality management which lead to slow growth of the company.

Second top barrier, with the weightage of $70.2 \%$, lack of commitment from top management is being chosen. Without the aid and decision by top management, subsidiary SMEs cannot implement TQM properly. SMEs managers also reluctant to implement TQM due to the changes needed to do, and due to the change of mind-set needed in the upper management as well as lower management.

With the weightage of $59.6 \%$, lack of objectives and strategies is being chosen as third biggest barrier. SMEs rarely dream big, which results in them being unambitious. The idea of them competing with big companies, gives them low confidence, which resulted them in settling down in their current position. The inability to dream big, results in lack of objectives and strategies is suitable to be chosen as one of the top barriers. This is being continued with quality system 


\section{International Journal of Science and Research (IJSR) \\ ISSN (Online): 2319-7064 \\ Index Copernicus Value (2013): 6.14 | Impact Factor (2014): 5.611}

based on detection (52.6\%) and lack of resources (49.1\%) as the $4^{\text {th }}$ and $5^{\text {th }}$ biggest barriers for TQM implementation

Table 6: Top 5 Barriers for TQM Implementation

\begin{tabular}{|c|c|c|c|c|}
\hline & \multicolumn{2}{|c|}{ Responses } & \multirow{2}{*}{\begin{tabular}{|c|} 
Percent \\
of \\
Cases
\end{tabular}} \\
\hline & & $\mathrm{N}$ & Percent & \\
\hline \multirow{11}{*}{$\begin{array}{c}\text { Top } 5 \text { Barriers for } \\
\text { TQM } \\
\text { Implementation }\end{array}$} & $\begin{array}{l}\text { Lack of commitment } \\
\text { from top management }\end{array}$ & 40 & 13.9 & 70.2 \\
\hline & $\begin{array}{c}\text { Lack of experience in } \\
\text { quality management }\end{array}$ & 44 & 15.3 & 77.2 \\
\hline & $\begin{array}{c}\text { Excessive reliance on } \\
\text { quality manual }\end{array}$ & 27 & 9.4 & 47.4 \\
\hline & Lack of resources & 28 & 9.7 & 49.1 \\
\hline & $\begin{array}{c}\text { Emphasis on short term } \\
\text { objectives }\end{array}$ & 26 & 9.0 & 45.6 \\
\hline & $\begin{array}{c}\text { Lack of objectives and } \\
\text { strategies }\end{array}$ & 34 & 11.8 & 59.6 \\
\hline & \begin{tabular}{|c} 
Quality system based on \\
detection
\end{tabular} & 30 & 10.4 & 52.6 \\
\hline & \begin{tabular}{|c|}
$\begin{array}{c}\text { Production department } \\
\text { given sole responsibility } \\
\text { for quality }\end{array}$ \\
\end{tabular} & 21 & 7.3 & 35.8 \\
\hline & $\begin{array}{c}\text { Quality department } \\
\text { given sole responsibility } \\
\text { for quality }\end{array}$ & 16 & 5.6 & 28.1 \\
\hline & $\begin{array}{l}\text { Lack of evaluation } \\
\text { procedures and } \\
\text { benchmark indices }\end{array}$ & 22 & 7.6 & 38.6 \\
\hline & Total & 288 & 100.0 & 505.3 \\
\hline
\end{tabular}

\section{Discussion}

The findings are basically to anticipate fulfilling few questions:

- What has been the most acknowledged and implemented quality activities so far?

- Which of the eight constructs or CSFs have the highest degree of practice?

- What are the boundaries for TQM implementation?

- How do the discoveries on the level of practice compare with results from different countries all over the world?

- What can be done to get a better results and data regarding TQM implementation in near future?

Since there were no recorded results of similar research in other areas of Malaysia, to get a better view on the status of implementation, other countries such as Ireland, Turkey and European countries were taken into consideration for comparison. Based on the survey result, $98.2 \%$ of the manufacturing SMEs surveyed had obtained a certified quality assurance system while $42.11 \%$ of the total respondents are found applying TQM in respective companies. A study in Irish manufacturing industries stated of having $66 \%$ of its respondent to have a certified quality assurance and $19 \%$ of them implementing TQM (Ismail, 1999). On the other hand, a study at Turkey stated that $30.3 \%$ of its respondents applying TQM although $75 \%$ percent have an ISO certification (Cebeci, 2001). Lastly, a local survey had done in Malaysian E\&E industry in 2003 shows that out of $75 \%$ who have ISO certification only an amount of 30.3\% applying TQM in their companies (Quek Eng Eng 2003).

Previously, it is regarded that Total Productive Maintenance (TPM) has always been the underutilized, least favour red quality activity adopted in Malaysian manufacturing companies (Zaleha 2000). Research done in USA shows that $60 \%$ of the respondents has quality circles while research in Turkey showed $38 \%$ of the respondents have quality circle. Research done by (Quek Eng Eng 2003) shows that Malaysian E\&E industry having 25\% of their respondent has quality circles in their company. Similar to this, this research paper shows that $68.4 \%$ of the manufacturing SMEs in Shah Alam have quality circle or quality improvement team. Based on this comparison, it can be seen Malaysian SMEs are not left out of the quality race and are improving from time to time.

It is noted, that Six Sigma Program and Design of experiment which is better known as Taguchi Method has a very low degree of usefulness (Adams 2003) states that with applying six sigma, small-business can become stronger, more intimate relationships with customers. Based on research done in the USA it is found out that the most important reason why SMEs did not implement six sigma is because they do not know about Six Sigma (35\%). This is followed by the insufficiency of resources which covers $26 \%$ and companies perceive their quality system is adequate, which covers the remaining $20 \%$ of the respondents. To increase the implementation of six sigma program in SMEs, more personnel with Six Sigma knowledge should be hired.

Majority of the research have uncovered that education and training is one of the exceptionally important element that aid in making TQM implementation success in the organization (Mann 1994). According to the research done by previous researcher, an amount of $79 \%$ of the respondent of Australian manufacturing companies has agreed that they have a progressing quality training program and it is being given extreme importance.

Based on the survey analysis, the respondents choose 5 top critical factors that affect the performance of the company. The 5 top critical factors are leadership and support from top management, selection application of tools and technique, adopting quality assurance system, conducting continuous improvement and sufficient financial resources. (Saraph 1989) in his research, found role of divisional top management and quality policy, role of quality department, training, product/ service design and supplier quality management as top 5 critical success factor. When comparing the research finding with previous finding the most common factor that being considered as critical factors that affect the performance of the company is management leadership, training and education, supplier quality management and sufficient financial resources. These factors are to be evaluated seriously in future in order to solve this factors as per required as attain high performance manufacturing SMEs.

Based on the survey analysis, the top 5 barriers for TQM implementation in Shah Alam manufacturing industries are

\section{Volume 5 Issue 1 January 2016}




\section{International Journal of Science and Research (IJSR) \\ ISSN (Online): 2319-7064 \\ Index Copernicus Value (2013): 6.14 | Impact Factor (2014): 5.611}

lack of experience in quality management, lack of commitment from top management, lack of objectives and strategies, quality system based on detection and lack of resources. In a different survey, the main barriers to growth in the SMEs are niche players, management resources, market intelligence and long- term strategy (McAdam R. 2002). SME managers face real competitive challenges. Most small ventures lack the brand recognition, channel power, market reach, and resources that sustain larger rivals. Lacking in these aspects, SME managers have hard time approving TQM implementation and content with the quality certification they have.

From all the finding investigated and examined in this sector, the level of TQM implementation among SMEs in Shah Alam has been obviously characterized. Despite the fact that these outcomes are not specifically equivalent and comparable to each other, as variety of angles must be taken into consideration to have a solid examination, nevertheless it should help to give some indication on the degree of accomplishment for Malaysian SMEs in the voyage towards being a power to be reckoned in the business sector. It also has shown and distinguished essential issues for organizations to consider particularly on areas found lack in implementation and barriers need to be overcome. Thus, a systematic and technical approach towards TQM should be done in order to have a significant growth in SMEs.

\section{Conclusion}

This research is designed to identify the current level of TQM implementation in Shah Alam manufacturing SMEs. It also designed to identify the critical success factors that affect the performance of the companies and to find barriers that stop them from implementing TQM in their company. Regarding this, it had been found that $42.11 \%$ of the respondents are applying TQM in their companies although $98.2 \%$ of the respondents have a certified quality assurance system. The majority of $57.9 \%$ did not apply TQM in their companies. It has been found out that internal quality audit, quality costing and benchmarking has the highest degree of usefulness in the respondent companies. Two quality activities that are being less utilized are Six Sigma program and Taguchi method. On finding the factors that affect TQM implementation in SMEs, respondent believe management leadership, resource management, education and training and supplier quality management as very important factor that should be solved soon. Respondent believe working environment is important also while measurement and feedback and systems and processes is regarded as not important factor that affect TQM implementation in SMEs. According to the research on critical factors, the respondent think leadership and support from top management, selective application of tools and technique, adopting quality assurance system, conducting continuous improvement and sufficient final resources are the 5 critical success factors that should be overviewed to increase the performance of the company. Lastly, the research intend to identify top 5 barriers for TQM implementation, and the respondents perceive lack of experience in quality management, lack of commitment, lack of objectives and strategies, quality system based on detection and lack of resources are the barriers that stops the SMEs from implementing TQM. Through this project, the researcher also learned to use some survey technique, and also software which can be come as handful in conducting future research. The researcher believes by overcoming the limitations of studies and by fulfilling the future research recommendation, successful implementation of TQM widely in SMEs can be expected thus contributing to the development of the country.

\section{References}

[1] Adams, C.W., Gupta, P. and Wilson, C. Six Sigma Deployment. Burlington: Butterworth-Heinemann, 2003.

[2] Ahire, S.L, and D.Y. Golhar. "Quality Management in large versus small firms."

[3] Journal of Small Business Management, 1996: 1-13.

[4] Ahire, S.L., Golhar, D.Y. "Development and Validation of TQM implementation constructs." Decision Sciences, 1996: 23-56.

[5] Barner, R. "Five Steps to a leadership competencies." Training and Development, 2000: 47-52.

[6] Binney. "Total Quality Management, and Guide to Management Principle." British Standard Institution, 1992: 20-56.

[7] Black, S.A. \& Porter, L.J. "Identification of critical success factors of TQM." Decision Sciences, 1996: 121.zairi

[8] Cebeci, U., Ahmet Beskese. "Total Quality Management and ISO 9000 applications in Turkey." The TQM Magazine, 2001: 60-75.

[9] Dhillon, B.S. Reliability, Quality and Safety for Engineers. Florida: CRC Press, 2005.

[10]Feagin, J., Orum, A., \& Sjoberg,g. A case for case study. Chapel Hill, NC: University of North Carolina Press, 1991.

[11]Ho, K.M., Samuel. "Change for the better via ISO 9000 and TQM." Management Decision, 1999: 381-385.

[12] Ismail, M.Y., Hashmi, M.S.J. "The state of Quality Management in the Irish manufacturing industry." Total Quality Management, 1999: 853-862.

[13] International Journal of Quality and Reliability Management, 2003: 700-715.

[14] Mann, R. S., Kehoe,D. "An evaluation of the effects of quality improvement activities on business performance." Journal of Quality \& Reliability Management, 1994: 28-44.

[15] McAdam R., Kelly M. "A business excellence approach to generic benchmarking in SMEs." Benchmarking: An International Journal, 2002: 7-27.

[16] Mohamad Reeduan Mustapha, Mohd Shaladdin Muda, Fauziah Abu Hasan. "A Survey of Total Quality Management in the Malaysian Small and Medium Sized Manufacturing Companies." International Journal of Humanities and Social Science, 2011: 118-120.

[17] Porter, L.J, and A.J Parker. "Total Quality Managementthe critical success factors."

[18] Total Quality Management, 1993: 8210-822.

[19]Porter, L.J., and S.A Black. "Identification of Critical Factors of TQM." Decision Sciences, 1996: 1-21. 
[20] Quek Eng Eng, Sha'ri Mohd Yusof. "A survey of TQM practices in the Malaysian electrical and electronic industry." Total Quality Management, 2003: 5-15.

[21] Saraph, J.V., Benson, P.G. \& Schroeder. "An instrument for measuring the critical factors of quality management." Decision Sciences, 1989: 810-829.

[22] Saylor, J.H. TQM Field Manual. USA: McGraw Hill, 1992.

[23] Yusof, S.M. \& Aspinwall, E.M. "Critical Success factors for total quality management implementation in small and medium enterprises." Total Quality Management, 1999: 803-809.

[24]Zaleha, Siti. "Kajian Terhadap Pengamalan Pengurusan Penyelegaraan oleh industri terpilih di Malaysia." 2000. 